\title{
FLUORIDE LEVEL IN PUBLIC WATER SUPPLIES OF CITIES FROM THE NORTHWEST REGION OF SÃO PAULO STATE, BRAZIL
}

\author{
CONCENTRAÇÃO DE FLÚOR NAS ÁGUAS DE ABASTECIMENTO PÚBLICO DE \\ MUNICÍPIOS DA REGIÃO NOROESTE DO ESTADO DE SÃO PAULO, BRASIL
}

Nemre Adas SALIBA ${ }^{1}$, Suzely Adas Saliba MOIMAZ², Ana Valéria Pagliari TIANO ${ }^{3}$

1- DDS, MSc, PhD, Full Professor, UNESP - São Paulo State University, Araçatuba Dental School, Araçatuba, São Paulo, Brazil.

2- DDS, MSc, PhD, Associate Professor, UNESP - São Paulo State University, Araçatuba Dental School, Araçatuba, São Paulo, Brazil.

3- DDS, MSc, Graduate student, Program of Preventive and Social Dentistry UNESP - São Paulo State University, Araçatuba, São Paulo, Brazil.

Corresponding address: Nemre Adas Saliba. - R. José Bonifácio, 1193. Vila Mendonça. Araçatuba- SP, Brazil. 16015-050

Tel: 55-18- 36363249 / 36363250. Fax: 55-18-36363332 - e-mail: nemre@foa.unesp.br.

Received: December 20, 2005 - Modification: March 29, 2006 - Accepted: August 25, 2006

\begin{abstract}
I t may be difficult for small and medium cities to obtain information about the fluoride content of public water, because of the lack of equipments and technicians. This study aimed to analyze the fluoride levels of the water supplied by the public treatment stations of 40 cities situated in the northwest region of São Paulo State, during a period of 6 months, to verify if fluoridation occurs in a continuous manner and if the fluoride levels are within the recommended. Maps of the water distribution system were obtained from the water treatment companies and utilized to randomize the addresses of the collection sites, so that they included all regions with treated water sources. One water sample by month was collected and analyzed in duplicate using an ion-specific-electrode. Samples with 0.6 to $0.8 \mathrm{mgF} / \mathrm{L}$ were considered acceptable. In the 38 cities that regularly provided the samples in the 6 months of the study, water from 144 collection sites was collected and a total of 864 samples were analyzed, of which 61.81 percent were classified as unacceptable. It was observed that 33 cities performed fluoridation but in 78.79 percent of these cities there were variations in the fluoride level among the sites and in the same site during the period of study. One can conclude that most of these cities do not control the fluoride levels in the public water, since fluoridation occurs in a discontinuous manner and in most of the situations not within the recommended concentrations.

Uniterms: Water fluoridation; Fluoride; Systemic fluoridation; Oral health.
\end{abstract}

\section{RESUMO}

$M$ La stecimento público em função da falta de infra-estrutura laboratorial e técnica. Este estudo realizou análises do teor de flúor das águas de abastecimento de 40 municípios situados na região noroeste do estado de São Paulo, durante 6 meses, para verificar se a adição ocorre de forma contínua e se os teores adicionados encontram-se dentro dos parâmetros recomendados. Mapas com a rede de distribuição de água dos municípios foram solicitados e utilizados para definir as regiões de coleta e sortear os endereços dos pontos, de forma que abrangessem todas as fontes de água tratada. Uma amostra de água de cada ponto foi coletada por mês e analisada em duplicata pelo método íon-eletrodo específico. Amostras com 0,6 a 0,8 mg F/L foram consideradas aceitáveis. Nos 38 municípios que enviaram as amostras regularmente nos 6 meses de estudo, a água de 144 pontos foi coletada, perfazendo um total de 864 amostras analisadas, das quais $61,81 \%$ foram classificadas como inaceitáveis. Constatou-se que 33 destes municípios realizavam a fluoretação, sendo que em $78,79 \%$ deles as concentrações de flúor variavam entre os pontos e no mesmo ponto ao longo do período. Pode-se concluir que a maioria destes municípios não mantém controle adequado sobre os níveis de flúor em sua água, pois a adição de flúor ocorre de forma descontínua e na maioria das vezes em teores fora dos parâmetros recomendados.

Unitermos: Fluoretação da água; Flúor; Fluoretação sistêmica; Saúde bucal. 


\section{INTRODUCTION}

The effect promoted by the use of fluoride on caries control is known all around the world ${ }^{2,5-7,21,27}$.

Many vehicles were proposed for both individual and community programs of fluoride use. For community programs, the public water fluoridation is an effective, safe and inexpensive measure, leading to caries reduction of up to $60 \%{ }^{1,15,21,25}$.

On the other hand, attenuation in the strength of the method has been reported: 15 to 20 percent, with the spread use of fluoride as a caries-preventive agent, in various forms, especially in dentifrices, and the successful educational and health preventive programs, aiming at dental plaque control $6,8,19$.

Several health organizations recommend the public water fluoridation in countries with high caries prevalence and inequalities in the access to oral health services, including the International Dental Federation (IDF), International Association for Dental Research (IADR), European Organization for Caries Research (ORCA), Pan-American Health Organization (PAHO) and World Health Organization (WHO) $)^{6,17,28}$.

The method was first introduced in Grand Rapids - USA in 1942. In Brazil, the first experience occurred in Baixo Guandu, Espírito Santo State, in 1953.

Ireland was the first country to acclaim a law that regulated the fluoridation of public water supplies, in 1960, while in Brazil, only in 1975 the Federal Law 6,050 on May $24^{\text {th }}, 1974$, regulated by the Act 76,872 on December $22^{\text {nd }}$, 1975 determined that fluoridation of the public water is an obligation wherever a public water treatment station exists ${ }^{17}$.

Ingestion of excessive doses of fluoride over longer time periods during the years of enamel formation in children may result in dental fluorosis, a condition marked by permanent and sometimes pronounced staining of the permanent teeth ${ }^{15,27}$.

Therefore, special attention must be given to the fluoride amount added in public water supplies, knowing that not the drinking water itself may contribute to the fluoride intake, but also the water used to manufacture or to cook foods and drinks, to prepare bottles, to rinse the teeth after brushing, in association with other sources of fluoride intake like supplements, foods and even incidental ingestion of toothpaste ${ }^{18}$.

Initially, it was recommended to add $1 \mathrm{mgF} / \mathrm{L}$ in the public water supplies ${ }^{14}$. In 1957, Galagan and Vermillon ${ }^{9}$ affirmed that the concentrations should be based on means of maximum temperature, since in places with warm climate, people consume more water than in places with cold climate. The Edict 518 on March 25th , 2004, establishes the proceedings and responsibilities related to the control and surveillance of the drinking water quality and explained that the maximum fluoride concentration in artificial fluoridated water must be $1.5 \mathrm{mg} / \mathrm{L}$. The Health Department of São Paulo State created the Resolutions SS 250/95 on August 15 ${ }^{\text {th }}$, 1995 and SS-65/02 on April 12 $2^{\text {th }}, 2005$, which approve water with 0.6 to $0.8 \mathrm{mgF} / \mathrm{L}^{22,23}$.
To assure those concentrations, the operational process control, performed by the water supplier company, must be confirmed by an external control performed by a surveillance system of the health authorities ${ }^{16,20,24}$.

There are studies reporting external control programs in distinct regions of the country and showing a great variation in the fluoride level of the water offered to the Brazilian population ${ }^{4,10-13,24}$.

The VI Regional Directory of Health (DIR VI-SP), situated in the Northwest region of São Paulo State, Brazil, has its administrative head at the city of Araçatuba. It is responsible for coordinating the health actions developed by the City Health Department of the 40 cities included in the DIR VISP.

This study aimed to analyze the fluoride levels of the water supplied by the public treatment stations of the 40 cities included in the DIR VI-SP, to verify if fluoridation occurs in a continuous manner and if the levels of fluoride are within the recommended.

\section{MATERIALAND METHODS}

\section{Definition of collection sites}

Engineers and technicians of the water treatment companies were interviewed to obtain information about the sites of water captation, water treatment stations and water distribution system, including wheels and reservoirs.

Maps of the water distribution system were obtained from the water treatment companies and utilized to randomize the addresses of the collection sites of the water samples, so that they included all regions with treated water sources in the cities. One to three collection sites were randomized in each area supplied for each water treatment station (Narvai, 2001). In some areas, the water distribution system was ramified and there was a mixture of water from different sites. In these sites, water samples were also collected. All the residences had the same chance to participate in the sampling. Table 1 shows the 40 cities that participated in the study and the number of collection sites in each.

\section{Samples Collection}

In a six-month-period, from November 2004 to April 2005, one water sample per month was collected in each address, in the same day in each city.

The samples were collected in polyethylene flasks, previously washed with deionized water and rinsed three times with the water that would be collected. These flasks were labeled according to the site, day and the person responsible for collection.

\section{Fluoride level analysis}

Fluoride concentrations of the water samples were analyzed in NEPESCO's laboratory (Research Nucleus for Collective Health), using an ion-specific electrode (Orion Research, Cambridge, MA, USA, model 9609) attached to an ion analyzer (Orion Research, Cambridge, MA, USA, model 710A), as described by Cury $^{5}$ (2001). 
These equipments were previously calibrated using a set of standards (containing 0.1, 0.2, 0.4, 0.8 and $1.6 \mathrm{mgF} / \mathrm{L}$ ) prepared from a $100 \mathrm{mgF} / \mathrm{L}$ stock solution (Orion 940907). A volume of $1 \mathrm{~mL}$ of each standard solution was buffered with $1 \mathrm{~mL}$ of Total Ionic Strength Adjustor Buffer (TISAB II) and analyzed in triplicates. The mean millivoltage potentials $(\mathrm{mV})$ were converted to mgF/L (Excel 2003, Microsoft software) using a standard curve with a coefficient correlation of $\mathrm{r}=$

TABLE 1- Cities included in DIR VI-SP, number of inhabitants in the urban zone and number of collection sites, 2005

\begin{tabular}{|c|c|c|}
\hline Cities & $\begin{array}{l}\text { Inhabitants } \\
\text { (urban zone)* }\end{array}$ & $\begin{array}{l}\text { Collection } \\
\text { sites }\end{array}$ \\
\hline Alto Alegre & 3,931 & 3 \\
\hline Andradina & 56,885 & 3 \\
\hline Araçatuba & 179,717 & 9 \\
\hline Auriflama & 13,982 & 3 \\
\hline Avanhandava & 9,365 & 3 \\
\hline Barbosa & 6,124 & 5 \\
\hline Bento de Abreu & 2,392 & 3 \\
\hline Bilac & 6,481 & 3 \\
\hline Birigui & 106,313 & 5 \\
\hline Braúna & 4,458 & 4 \\
\hline Brejo Alegre & 2,515 & 3 \\
\hline Buritama & 14,536 & 5 \\
\hline Castilho & 15,161 & 6 \\
\hline Clementina & 5,730 & 5 \\
\hline Coroados & 4,659 & 3 \\
\hline Gabriel Monteiro & 2,885 & 3 \\
\hline Glicério & 4,550 & 5 \\
\hline Guaraçaí & 9,270 & 7 \\
\hline Guararapes & 30,193 & 3 \\
\hline Guzolândia & 3,821 & 3 \\
\hline Ilha Solteira & 25,427 & 3 \\
\hline Itapura & 3,891 & 3 \\
\hline Lavínia & 4,939 & 5 \\
\hline Lourdes & 2,221 & 3 \\
\hline Luiziânia & 4,347 & 3 \\
\hline Mirandópolis & 26,878 & 6 \\
\hline Murutinga do Sul & 4,089 & 3 \\
\hline Nova Castilho & 1,026 & 3 \\
\hline Nova Independência & 2,106 & 3 \\
\hline Nova Luzitânia & 2,814 & 3 \\
\hline Penápolis & 58,613 & 3 \\
\hline Pereira Barreto & 24,680 & 3 \\
\hline Piacatu & 4,679 & 3 \\
\hline Rubiácea & 2,148 & 3 \\
\hline Sto Ant. do Aracanguá & 6,882 & 5 \\
\hline Santópolis do Aguapeí & 3,789 & 3 \\
\hline Sud Mennucci & 7,465 & 3 \\
\hline Suzanápolis & 2,886 & 3 \\
\hline Turiúba & 1,775 & 3 \\
\hline Valparaíso & 19,842 & 6 \\
\hline Total & 693,465 & 154 \\
\hline
\end{tabular}

* IBGE (2005)
0.999. The water samples in duplicates were buffered with an equal volume of TISAB II and the mean reproducibility of readings was $=95$ percent.

\section{Classification of the samples}

According to their fluoride concentrations, the water samples were classified as recommended by the Health Department of São Paulo State ${ }^{22,23}$ and described by Narvai ${ }^{16}$ (2001). Samples with 0.6 to $0.8 \mathrm{mgF} / \mathrm{L}$ were considered acceptable. Samples with concentrations above or under these values were considered unacceptable.

\section{Collection site classification}

Fluoridation in a site was considered adequate when the fluoride level of at least 5 samples in the 6 months of collection were classified as acceptable.

\section{RESULTS}

Fortunately, just one of the 40 cities participating in this study did not provide the samples in two months (March and April) and another city did not provide the samples in one month (April). In the 38 cities that regularly provided the samples in the 6 months of the study (95 percent), water from 144 collection sites was collected and a total of 864 samples were analyzed.

Figure 1 illustrates the classification of the 864 samples.

The 144 sites were classified as shown in Figure 2. Those sites in which the fluoridation process was not performed were included among the sites classified as inadequate.

The fluoridation status of the 38 cities during the period of this study is described in Table 2. Among those 33 cities that performed the public water fluoridation, 7 (21.21 percent)

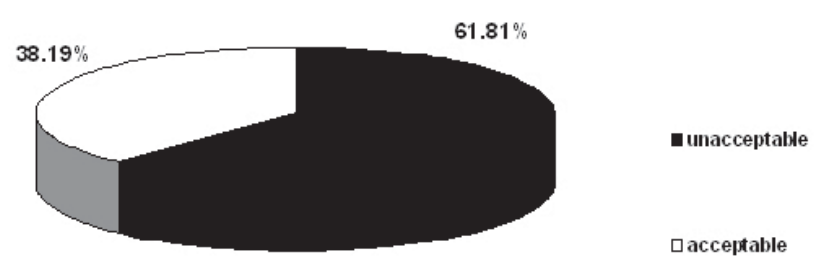

FIGURE 1- Percentage of the 864 water samples collected in the region of Araçatuba, classified according to fluoride concentration. 2005

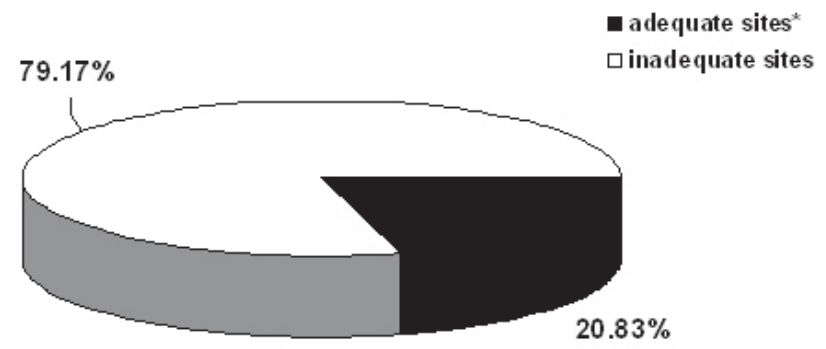

FIGURE 2- Percentage of the144 sites classified according to the fluoride concentration of the water samples collected in the region of Araçatuba. 2005

* 5 or more acceptable samples in 6 months of analysis 
presented constant levels, considered adequate, in the study period.

The distribution of the 38 cities according to the fluoridation status of their sites is observed in Figure 3. The 3 cities that did not fluoridate their water supplies and the 2 cities that initiated fluoridation during the study were included among the cities that had all sites inadequate.

\section{DISCUSSION}

In 1970, Uchoa and Saliba ${ }^{26}$ reported the first recommendation of adjustment of the fluoride level in public water supplies in Brazil, based in the results of an endemic fluorosis study that verified that children from Pereira Barreto city, São Paulo State, were exposed to 2.5 to 17.5 $\mathrm{mgF} / \mathrm{L}$ water, originated from deep wells. It was suggested to mix the water from the wells with water from Tiete River to reach acceptable levels.

In order to obtain benefits from public water fluoridation, it is necessary to evaluate the entire fluoridation process so that adequate levels are maintained. This control must be performed by the company responsible for the water treatment and distribution (operational process control) and confirmed by another health authority (external control) ${ }^{16}$. In some cases, for small and medium cities it is difficult to obtain information about the fluoride content of public water, because of the lack of equipments and technicians ${ }^{20}$.

The present study analyzed the public water fluoride level of the 40 cities included in DIR VI (São Paulo State) for 6 months.

Of the 864 analyzed samples 61.81 percent (534) were classified as unacceptable, according to the fluoride levels presented (Figure 1). Of the 534 unacceptable samples, 87.07 percent (465) were found to be under the minimum acceptable (0.6 mgF/L).

Other studies conducted in the same region of the country (southeast) also detected irregular fluoride concentrations in most of the analyzed samples ${ }^{4,1-13,24}$.

On the other hand, in São Paulo city, more than 93 percent of the samples were classified as excellent in a 10-year study that analyzed the monthly registrations of the fluoride levels by the local health authority. However, there were variations in the amount of sites considered adequate during the 10 years: 56.5 to 96.8 percent ${ }^{16}$.

Variability and discontinuation among the sites were also registered in a study conducted in the south region of the country, where 50 percent of the sites presented inadequate fluoride levels in 24 months of analysis ${ }^{10}$.

In the present study, only 20.83 percent of the sites were classified as adequate (Figure 2). Only in these sites, fluoridation would benefit the residents by controlling caries disease and reducing the caries lesion progression, without exposing people to the risk of dental fluorosis.

Among the 38 cities that provided all the samples, 86.84 percent (33) fluoridated the public water supplies (Table 2) but only 21.21 percent (7) of these 33 presented adequate fluoride concentrations in all sites. In 26 cities two situations were shown: there were variations in the fluoride level among the sites in the same month, which may indicate that the residents who drink water from these sites were not receiving the caries-preventive benefit from water fluoridation; and there were variations in the fluoride level in the same site on different months. The second situation is even more worrisome because it may indicate an inadequate control of the fluoride level in these sites.

Saliba, et al. ${ }^{20}$ (2004) reported information about the water fluoridation given by the oral health authorities of the same cities participating in the present study. It was disclosed that 79.3 percent of the cities maintain acceptable fluoride levels.

Analyzing the results of the present study, it may be stated that the information provided by the oral health authorities of these cities are not trustable. Therefore, most of these cities do not control the public water fluoridation in an adequate manner.

Based on the results from this study, maintenance of an external control program to help the surveillance and monitoring of public water fluoridation in these cities is recommended, since the absence of water fluoridation or fail in its continuation is illegal, scientifically unsustainable and socially unfair, according to the Brazilian's Health Ministry ${ }^{3}$.
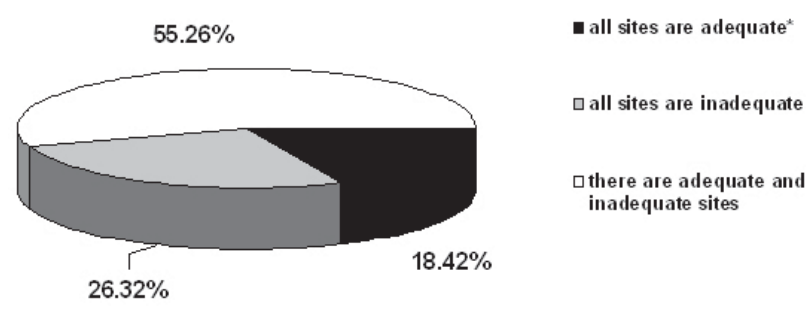

FIGURE 3- Percentage of the 38 cities from the region of Araçatuba according to classification of the collection sites. 2005

* 5 or more acceptable samples in 6 months of analysis

TABLE 2- Fluoridation status of the 38 cities from the region of Araçatuba in the study period. 2005

\section{FLUORIDATION STATUS}

Fluoridation of the public water supplies

Non-fluoridation of the public water supplies

Initiating fluoridation of the public water supplies

TOTAL 


\section{CONCLUSION}

It is evident that most of the cities included in DIR VI do not control the fluoride levels in the public water, since fluoridation occurs in a discontinuous manner and in most of the situations not within the recommended concentrations.

\section{ACKNOWLEDGMENTS} study.

The authors thank CNPq for financially supporting this

\section{REFERENCES}

1- Arcieri RM, Saliba CA, Saliba NA, Moimaz SAS, Sundefeld MLMM. Redução da cárie dental em escolares de Araçatuba, após 21 anos de fluoretação da água de abastecimento. Rev Fluminense de Saúde Coletiva. 1998;3:41-8.

2- Brambilla E. Fluoride - is it capable of fighting old and new dental diseases? Caries Res. 2001;35(sp.1):6-9.

3- Brasil. Ministério da Saúde. Conselho técnico de 24 de agosto de 1999, Comitê Técnico Científico (CTC). Área técnica de saúde bucal do Ministério da Saúde, sobre o método de fluoretação das águas de abastecimento público. Brasília: Ministério da Saúde; 1999.

4- Buzalaf MAR, Granjeiro JM, Damante CA, Ornela F. Fluctuations in public water fluoride level in Bauru, Brazil. J Public Health Dent. 2002;62(3):173-6.

5- Cury JA, Lima YBO, Vieira Filho W. Análise de flúor com eletrodo específico. UNICAMP: Campinas; 2001. 27 p.

6- Cury JA, Tabchoury CPM. Determination of appropriate exposure to fluoride in non-eme countries in the future. J Appl Oral Sci. 2003;11(2):83-95.

7- Cury JA. O uso do flúor e controle de cárie como uma doença. In: Baratieri LN, Monteiro Junior S, Andrada MAC, Vieira LCC, Ritter AV, Cardoso AC. Dentística restauradora: bases de possibilidades. São Paulo: Ed. Santos; 2001. p. 33-68.

8- Fejerskov O, Kidd E. Cárie dentária: a doença e seu tratamento clínico. São Paulo: Ed. Santos; 2005. 370 p.

9- Galagan DJ, Vermillion JR. Determining optimum fluoride concentrations. Public Health Rep. 1957;72(6):491-3.

10- Lima FG, Lund RG, Justino LM, Demarco FF, Del Pino FAB, Ferreira R. Vinte e quatro meses de heterocontrole da fluoretação das águas de abastecimento público de Pelotas, Rio Grande do Sul, Brasil. Cad Saúde Pública. 2004;20(2):422-9.

11 - Maia LC, Valença AMG, Soares EL, Cury JA. Controle operacional da fluoretação da água em Niterói, Rio de Janeiro, Brasil. Cad Saúde Pública. 2003;19(1):61-7.

12 - Maia LP, Rigolizzo DS, Ramires I, Buzalaf MAR. Um ano de heterocontrole da fluoretação da água de abastecimento público do município de Bauru-SP [resumo n Ic064]. Brazilian Oral Res. 2005;19(Suppl):96.

13- Modesto A, Tanaka FHR, Freitas AD, Cury JA. Avaliação da concentração de flúor nas águas de abastecimento público do Rio de Janeiro. Rev Bras Odontol. 1999;56(5):217-21.
14- Murray JJ, Naylor MN. Fluorides and Dental Caries. In: Murray JJ. Prevention of Oral Disease. Oxford: Oxford University Press; 1996. p.32-67.

15- Murray JJ. O uso apropriado do flúor. São Paulo: Ed. Santos; 1992

16- Narvai PC. Vigilância sanitária da fluoretação das águas de abastecimento público no município de São Paulo, Brasil no período de 1990-1999. São Paulo; 2001. [Tese - Faculdade de Saúde Pública da USP].

17- Oliveira AGRC, Domingues JEG. Flúor em odontologia. In: UFRN - Odontologia preventiva e social: textos selecionados. Natal: PROIN EDUFRN; 1997. p.154-78.

18- Paiva SM, Lima YBO, Cury JA. Fluoride intake by Brazilian children from two communities with fluoridated water. Community Dent Oral Epidemiol. 2003;31(3):184-91.

19- Petersen PE, Lennon MA. Effective use of fluorides for the prevention of dental caries in the 21st century: the WHO approach. Community Dent Oral Epidemiol. 2004;32: 319-21.

20- Saliba NA, Moimaz SAS, Casotti CA, Saliba O. A fluoretação na região nordeste do estado de São Paulo. UFES Rev Odontol. 2004;6(3):37-48.

21 - Saliba NA, Vieira SMM, Rey CR, Arcieri RM, Saliba O, Ayres JPS. Prevalência de cárie dentária em escolares de Araçatuba, após cinco anos de fluoretação da água de abastecimento. Odontol Mod.1981;8(3):6-8.

22- São Paulo. Secretaria de Saúde. Resolução SS-250 de 15/08/1995. Diário Oficial do Estado de São Paulo. 1995 ago 16; Sec.I:11.

23- São Paulo. Secretaria de Saúde. Resolução SS-65 de 12/04/2005. Diário Oficial do estado de São Paulo. 2005 abr 13; Sec.I:18.

24- Silva FSJB, Moimaz SAS, Garbin CAS, Saliba NA, Werner CWA. Heterocontrole do nível de flúor da água de abstecimetno público da cidade de Lins-SP. Rev Fac Odontol Lins. 2004;16(1):22-8.

25- Tavares PG, Bastos JRM. Concentração de flúor na água de abastecimento: cárie dental, fluorose e nível de flúor na urina em escolares de Bauru - SP. Rev Assoc Paul Cir Dent. 1999;53(5):40715 .

26- Uchoa HW, Saliba NA. Prevalência de fluorose dentária no município de Pereira Barreto. Bol Serviço de Odontologia Sanitária. 1970;6(3):11-6.

27- Whitford GM. The metabolism and toxicity of fluoride. $2^{\text {nd }}$ ed. Basel: Karger; 1996.

28-Zimmer S, Jahn KR, Barthel CR. Recommendations for the use of fluoride in caries prevention. Oral Health Prev Dent. 2003;1(1):4551. 